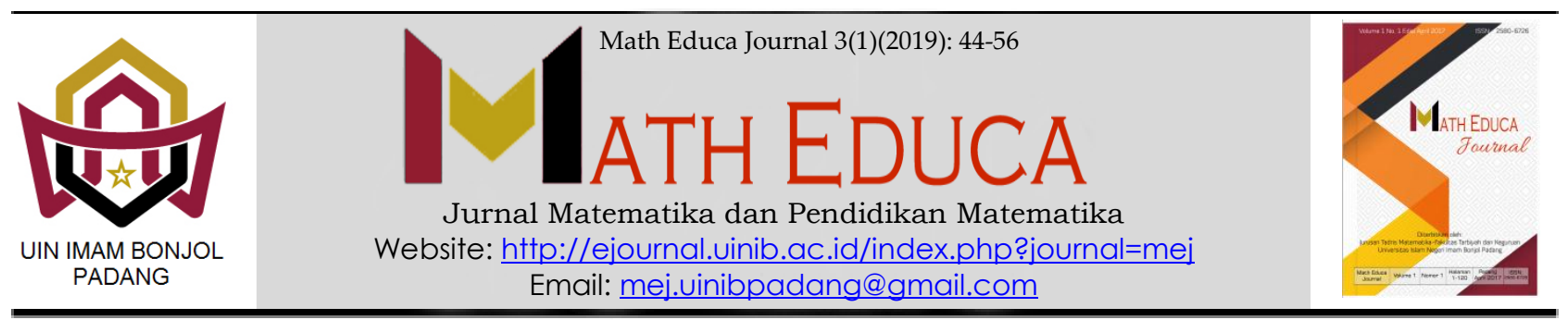

\title{
KEMAMPUAN KOMUNIKASI MATEMATIS PESERTA DIDIK YANG DIAJAR DENGAN METODE PROBING-PROMPTING LEARNING PADA KELAS VII MTSN BUNGUS TELUK KABUNG PADANG TAHUN AJARAN 2017/2018
}

\author{
1Sasmi Nelwati, 2 Yelpa Yeni \\ Tadris Matematika, Fakultas Tarbiyah dan Keguruan, UIN Imam Bonjol Padang, Indonesia \\ Email:'sasminelwati@uinib.ac.id, 2yelpayeni11@yahoo.com
}

Received: January 2019; Accepted: March 2019; Published: April 2019

\begin{abstract}
Abstrak
Kemampuan komunikasi matematis merupakan salah satu tujuan pembelajaran yang diharapkan dapat dikembangkan dalam pembelajaran matematika. Berdasarkan hasil observasi di MTsN Bungus Teluk Kabung Padang menunjukkan bahwa kemampuan komunikasi matematis peserta didik masih rendah. Tujuan penelitian ini adalah untuk mengetahui kemampuan komunikasi matematis peserta didik kelas VII MTsN Bungus Teluk Kabung Padang tahun ajaran 2017/2018 yang diajar dengan menggunakan Metode ProbingPrompting Learning. Jenis penelitian ini adalah eksperimen semu (Quasi Experimental Research) dengan rancangan penelitian Randomized Control Group Only Design. Populasi penelitian adalah peserta didik kelas VII MTsN Bungus Teluk Kabung Padang. Data kemampuan komunikasi matematis peserta didik dianalisis dengan menggunakan uji-t setelah memenuhi uji normalitas dan homogenitas. Berdasarkan hasil penelitian, kemampuan komunikasi matematis peserta didik kelas eksperimen lebih tinggi dari pada kelas kontrol. Setelah dilakukan analisis, skor rata-rata nilai tes kelas eksperimen 80,00 dan skor rata-rata nilai tes kelas kontrol 73,42. Hasil dari uji hipotesis menggunakan uji-t, diperoleh $t_{\text {hitung }}>t_{\text {tabel }}(1,82>1,66)$ dengan $\alpha=0,05$ pada taraf kepercayaan 95\%, maka keputusannya adalah $\mathrm{H}_{0}$ ditolak dan $\mathrm{H}_{1}$ diterima.
\end{abstract}

Kata Kunci : Kemampuan Komunikasi Matematis, Metode Probing-Prompting Learning

\section{Abstract}

Communication ability of mathematic is one of purpose in learning that hoped can developed in mathematic learning. Base on observation result in MTsN Bungus Teluk Kabung Padang show that communication ability of mathematic student still low. The purpose of this research is to know about students ability on mathematics communication at grade VII MTsN Bungus Teluk Kabung Padang academic year 2017/2018 that taught by Probing-Prompting Learning Method. This type of research is quasi experimental (Quasi Experimental Research) with Randomized Control Group Only Design. Population in this research is student in grade VII MTsN Bungus Teluk Kabung Padang academic year 2017/2018. Data collection method use are posttest obtained is analyzed by using $t$ - test after normality test and homogenity test. Based on the research result, mathematical communication ability of experment class student is higher than control class. After doing analysis, the average score of the experiment class is 80,00 while the control class is 73,42. After hypothesis testing using t-test, obtained $t_{\text {count }}>t_{\text {table }}(1,82>1,66)$ with $\alpha=0,05$ on the level trust is $95 \%$, then the decision is $H_{0}$ rejected and $H_{1}$ accepted.

Keyword: Communication Abiliy Of Mathematic, Probing-Prompting Learning Method.

\footnotetext{
*Corresponding author.

Peer review under responsibility UIN Imam Bonjol Padang.

(C) 2018 UIN Imam Bonjol Padang. All rights reserved.

p-ISSN: 2580-6726

e-ISSN: 2598-2133
} 


\section{PENDAHULUAN}

Pendidikan merupakan fenomena manusia yang fundamental, yang juga mempunyai sifat konstruktif dalam hidup manusia. Oleh sebab itu manusia dituntut untuk mampu mengadakan refleksi ilmiah tentang pendidikan tersebut, sebagai pertanggung jawaban terhadap perbuatan yang dilakukan yaitu mendidik dan dididik (Hasbullah, 2006: 6). Sebagai bagian dari pendidikan, matematika merupakan ilmu yang memiliki peranan penting dalam membina dan membentuk manusia yang berkualitas tinggi. Selain sebagai suatu disiplin ilmu yang terus tumbuh dan berkembang untuk dirinya, matematika juga berperan melayani kebutuhan ilmu pengetahuan dan pengembangannya. Suherman, dkk (2003:15) menyatakan bahwa "Matematika adalah sarana berpikir; matematika adalah logika pada masa dewasa; matematika adalah ratunya ilmu sekaligus pelayannya; matematika adalah sains formal yang murni; matematika adalah sains yang memanipulasi simbol; matematika adalah ilmu yang mempelajari hubungan pola, bentuk, dan struktur".

Berdasarkan Standar isi Permendiknas No. 22 tahun 2006, menyatakan bahwa tujuan pembelajaran matematika bertujuan agar peserta didik memiliki kemampuan sebagai berikut: 1) memahami konsep, 2) menggunakan penalaran, 3) memecahkan masalah, 4) mengkomunikasikan, 5) memiliki sikap mengahargai kegunaan matematika dalam kehidupan yaitu memiliki rasa ingin tahu minat (Shadiq, 2009:2).

Kemampuan komunikasi yang tertuang dalam permendiknas No. 22 tahun 2006 tentang standar isi (SI) merupakan salah satu dari kompetensi yang harus dimiliki oleh peserta didik. Kemampuan mengkomunikasikan gagasan yang harus dimiliki peserta didik tersebut adalah kemampuan komunikasi matematis yakni bagaimana peserta didik mampu menggunakan matematika sebagai alat komunikasi dalam menyampaikan ide-ide atau gagasan matematika melalui simbol, tabel, diagram atau gambar. Dengan demikian, kemampuan komunikasi matematis menjadi kemampuan yang harus dikembangkan pada diri peserta didik. Akan tetapi, kemampuan komunikasi matematis sering terabaikan dalam pembelajaran matematika sehingga mengakibatkan rendahnya hasil belajar peserta didik.

Rendahnya hasil belajar peserta didik tersebut dapat dilihat dari lembaran hasil ulangan harian peserta didik yang memuat soal komunikasi matematis. Salah satu soal tersebut diantaranya sebagai berikut, "Suatu persegi panjang mempunyai panjang $(4 x-2 y) \mathrm{cm}$ dan lebarnya sama dengan $1 / 2$ dari panjangnya. Tentukan keliling dan luas persegi panjang tersebut dalam variabel $x$ dan $y$ ?"

Soal ini memuat indikator kemampuan komunikasi matematis yaitu: (1) menyajikan pernyataan matematika secara lisan, tertulis, 
gambar, atau diagram, (2) melakukan dugaan,

(3) melakukan manipulasi matematika, (4) menarik kesimpulan. Dalam menyelesaikan masalah ini, sebagian besar peserta didik memberikan jawaban yang kurang tepat. Salah satu lembar jawaban peserta didik tersebut dapat dilihat pada gambar 1 berikut :

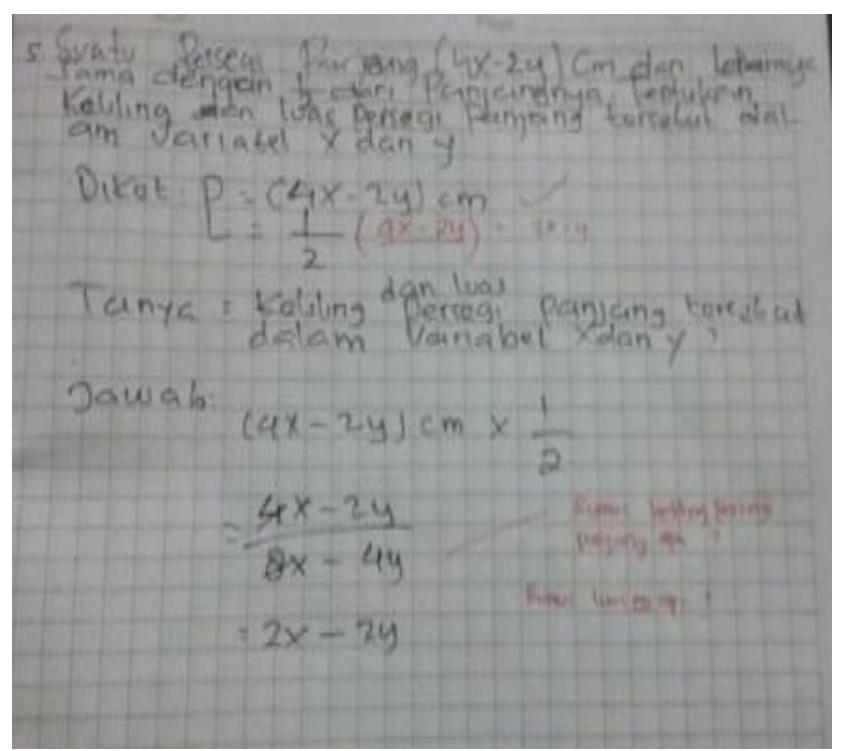

\section{Gambar 1. Jawaban Peserta Didik}

Dari jawaban yang diberikan peserta didik terlihat belum bisa memahami soal dengan baik. Pada langkah pertama terlihat bahwa peserta didik belum bisa menyajikan pernyataan matematika secara tertulis dengan baik. Jawaban yang benar yaitu diketahui panjang $=4 x-2 y$ dan lebar $=1 / 2(4 x-2 y)$. Peserta didik masih salah dalam mengajukan dugaan, seperti yang terlihat pada lembar jawaban bahwa peserta didik tidak menuliskan rumus keliling dan luas persegi panjang. Jawaban yang diinginkan yaitu peserta didik menuliskan rumus keliling persegi panjang $=2 p+2 l$ dan luas persegi panjang $=$ panjang $\times$ lebar. Peserta didik tidak mampu memanipulasi matematika dan menarik kesimpulan dengan tepat seperti yang terlihat pada lembar jawaban peserta didik. Jawaban yang diharapkan yaitu peserta didik mampu menuliskan jawaban seperti berikut:

$$
\begin{aligned}
\text { Keliling } & =2(4 x-2 y)+2(2 x-y) \\
& =8 x-4 y+2 x-2 y \\
& =10 x-6 y . \\
\text { Luas } & =(4 x-2 y) \times(2 x-y) \\
& =8 x^{2}-4 x y-4 x y+2 y^{2} \\
& =8 x^{2}-8 x+2 y^{2} .
\end{aligned}
$$

Jadi, keliling dan luas persegi panjang tersebut adalah $10 x-6 y$ dan $8 x^{2}-8 x+2 y^{2}$.

Rendahnya kemampuan komuniksi matematis peserta didik merupakan persoalan yang cukup memperihatinkan, karena peserta didik tidak akan dapat menarik kesimpulan dengan baik dan benar dalam menyelesaikan persoalan matematisnya. Jika permasalahan ini tidak diselesaikan dengan tepat, dapat mengakibatkan kemampuan komunikasi matematis peserta didik akan terhenti sampai disana saja, atau memungkinkan terjadinya penurunan kemampuan komunikasi dari yang telah dimilikinya sekarang. Untuk itu perlu dilakukan upaya-upaya agar kemampuan komunikasi matematis peserta didik dapat meningkat.

Kemampuan komunikasi matematis peserta didik dapat ditingkatkan jika mereka terbiasa untuk berpikir terbuka dan mengaitkan pengetahuan yang telah mereka miliki sebelumnya. Pengetahuan dapat diperoleh dari kehidupan sehari-hari maupun yang diperoleh dari pembelajaran matematika. 
Masalah-masalah ini dapat diatasi salah satunya dengan menerapkan metode pembelajaran yang dapat membuat peserta didik termotivasi secara aktif. Metode pembelajaran lebih bersifat prosedural, yaitu berisi tahapan tertentu (Hamzah, 2011: 2). Salah satu metode tersebut yaitu Metode Probing-Prompting Learning.

\section{Probing-Prompting Learning adalah} pembelajaran dengan pendidik menyajikan serangkaian pertanyaan yang sifatnya menuntun dan menggali gagasan peserta didik, sehingga dapat meningkatkan proses berpikir yang mampu mengaitkan pengetahuan dan pengalaman peserta didik dengan pengetahuan baru yang sedang dipelajari. Selanjutnya peserta didik mengonstruksi konsep-prinsip-aturan menjadi pengetahuan baru, dengan demikian pengetahuan baru tidak diberitahukan (Huda, 2013: 281).

Jacobsen dalam bukunya yang berjudul Methods for Teaching tahun 1989: 149, menyatakan bahwa Probing (Question) secara bahasa kata "Probing" memiliki arti menggali atau melacak, sedangkan menurut istilah Probing berarti berusaha memperoleh keterangan yang lebih jelas atau lebih mendalam. Prompting (Question) secara bahasa "Prompting" berarti "mengarahkan, menuntun", sedangkan menurut istilah adalah pertanyaan yang diajukan untuk memberi arah kepada peserta didik dalam proses berfikirnya( Abdul Gofur: 2017: 1).
Penggunaan Metode Probing-Prompting Learning pada pembelajaran matematika dapat membuat peserta didik belajar lebih bermakna, karena peserta didik tidak hanya menerima saja, tapi peserta didik dapat menemukan pengetahuan baru dengan menggunakan pengetahuan yang telah mereka miliki, sehingga peserta didik tidak lagi mengingat langkah-langkah untuk menyelesaikan suatu persoalan matematis yang diberikan.

Langkah-langkah Metode ProbingPrompting Learning (Jacobsen, 1989:149) sebagai berikut: 1) Pendidik menghadapkan peserta didik pada situasi baru, misalkan dengan memberikan gambar, rumus, atau situasi lainnya yang mengandung permasalahan, 2) Menunggu beberapa saat untuk memberikan kesempatan kepada peserta didik merumuskan jawaban atau melakukan diskusi kecil dalam merumuskan permasalahan, 3) Pendidik mengajukan persoalan yang sesuai dengan Tujuan Pembelajaran Khusus (TPK) atau indikator kepada seluruh peserta didik, 4) Menunggu beberapa saat untuk memberikan kesempatan kepada peserta didik untuk merumuskan jawaban atau melakukan diskusi kecil, 5) Menunjuk salah satu peserta didik untuk menjawab petanyaan, 6) Jika jawabannya tepat maka guru meminta tanggapan lain kepada peserta didik lain tentang jawaban tersebut untuk meyakinkan bahwa seluruh peserta didik terlibat dalam kegitan yang sedang berlangsung. Namun, jika peserta didik 
tersebut mengalami kemacetan jawaban atau jawaban yang di berikan kurang tepat, tidak tepat, atau diam, maka pendidik mengajukan pertanyaan-pertanyaan lain yang jawabannya merupakan petunjuk jalan penyelesaian jawaban. Kemudian, pendidik memberikan pertanyaan yang menuntut peserta didik berpikir pada tingkat yang lebih tinggi, hingga peserta didik dapat menjawab pertanyaan sesuai dengan kompetensi dasar atau indikator. Pertanyaan yang diajukan pada langkah ke enam ini sebaiknya diberikan pada beberapa peserta didik yang berbeda agar seluruh peserta didik terlibat dalam seluruh kegiatan Probing-Prompting,dan 7) Pendidik mengajukan pertanyaan akhir pada peserta didik yang berbeda untuk lebih menekankan bahwa TPK/indikator tersebut benar-benar telah di pahami oleh seluruh peserta didik.

Kelebihan dari Metode Probing-Prompting Learning (Istarani dan Ridwan, 2014:74) adalah: a) Setiap peserta didik mau tidak mau harus berpartisipasi aktif, karena peserta didik harus siap-siap menunggu giliran untuk ditanya, b) Peserta didik tidak bisa menghindar dari proses pembelajaran, karena setiap peserta didik telah disiapkan pertanyaan oleh pendidik, dan c) Setiap saat peserta didik bisa dilibatkan dalam proses tanya jawab, karena peserta didik bisa saja ditanya tanggapannya tentang hasil jawaban jawaban peserta didik lain.

Kelemahan dari Metode Probing-Prompting Learning (Istarani dan Ridwan, 2014:74) adalah: a) Kemungkinan akan terjadi suasana tegang, karena peserta didik takut diajukan pertanyaan kepadanya, b) Membuat pertanyaan yang valid atau sesuai dengan kemampuan daya pikir peserta didik sangat sulit, c) Penilaian hanya dilakukan dalam bentuk jawaban lisan saja, sementara jawaban secara tertulis tidak, dan d) Peserta didik ada ragu-ragu dalam menjawab pertanyaan, atau jadi salah kerana takut menjawab pertanyaan yang dilontarkan pendidik kepada peserta didik.

\section{Penggunaan Metode Probing-Prompting} Learning pada pembelajaran matematika dapat membuat peserta didik belajar lebih bermakna, karena peserta didik tidak hanya menerima saja, tapi peserta didik dapat menemukan pengetahuan baru dengan menggunakan pengetahuan yang telah mereka miliki, sehingga peserta didik tidak lagi mengingat langkah-langkah untuk menyelesaikan suatu persoalan matematis yang diberikan.

Penelitian ini salah satunya relevan dengan penelitian Widya Ananda Putri (Skripsi: 2010) dengan judul: Pengaruh Penerapan Metode Probing-Prompting Terhadap Kemampuan Penalaran Matematis Siswa Kelas VIII SMP N 13 Padang. Hasil penelitian ini adalah pembelajaran dengan menggunakan metode Probing-Prompting dapat mempengaruhi kemampuan penalaran matematis peserta didik. Perbedaan dari penelitian Widya Ananda Putri dengan penelitian yang dilakukan peneliti adalah terletak pada subyek penelitian dan masalah yang diteliti, dimana masalah yang akan diteliti pada penelitian ini adalah 
kemampuan komunikasi matematis peserta didik kelas VII MTsN Bungus Teluk Kabung Padang tahun ajaran 2017/2018, sementara pada penelitian Widya Ananda Putri masalah yang diteliti yaitu kemampuan penalaran matematis peserta didik kelas VIII SMPN 13 Padang.

Penelitian ini bertujuan untuk mengetahui kemampuan komunikasi matematis peserta didik kelas VII MTsN Bungus Teluk Kabung Padang yang diajar dengan menggunakan Metode Probing-Prompting Learning lebih tinggi daripada kemampuan komunikasi matematis yang tidak diajar dengan Metode ProbingPrompting Learning.

Hipotesis dari penelitian ini adalah Kemampuan komunikasi matematis peserta didik kelas VII MTsN Bungus Teluk Kabung Padang yang diajar dengan Metode ProbingPrompting Learning lebih tinggi daripada kemampuan komunikasi matematis peserta didik yang tidak diajar dengan Metode ProbingPrompting Learning tahun ajaran 2017/2018.

\section{METODE}

\section{Jenis Penelitian}

Jenis penelitian adalah penelitian eksperimen semu (quasi experimental research) dengan rancangan penelitian Randomized Control Group Only Design yang disajikan sebagai berikut:
Tabel 1. Randomized Control Group Only Design

\begin{tabular}{lcc}
\hline Kelas & Perlakuan & Tes Akhir \\
\hline Eksperimen & $\mathrm{X}$ & - \\
Kontrol & $\mathrm{T}_{1}$ & $\mathrm{~T}_{2}$ \\
\hline Sumber: Suryabrata(2008: 104) &
\end{tabular}

Keterangan:

$\mathrm{X}=$ Pembelajaran menggunakan Metode Probing-Prompting Learning

$\mathrm{T}_{1}=$ Tes akhir kelas eksperimen

$\mathrm{T}_{2}=$ Tes akhir kelas kontrol

\section{Waktu dan Tempat}

Penelitian dilakukan dari tanggal 10 Oktober 2017 sampai dengan 31 Oktober 2017 di MTsN Bungus Teluk Kabung Padang.

\section{Populasi dan Sampel}

Populasi adalah wilayah generalisasi yang terdiri atas obyek/subyek yang mempunyai kualitas dan karakteristik tertentu yang ditetapkan oleh peneliti untuk dipelajari dan kemudian ditarik kesimpulannya (Sugiyono, 2010:117). Populasi pada penelitian ini adalah seluruh peserta didik kelas VII MTsN Bungus Teluk Kabung Padang tahun ajaran 2017/2018 dengan jumlah populasi 208 peserta didik.

Sampel adalah bagian dari jumlah dan karakteristik yang dimiliki oleh populasi tersebut. Sampel yang dipilih dalam penelitian ini haruslah menggambarkan karakteristik dari suatu populasi (Sugiyono, 2010:118). Sesuai dengan masalah yang diteliti dan metode penelitian yang digunakan, maka dibutuhkan dua kelas yaitu kelas eksperimen dan kelas kontrol. Cara pengambilan sampel menggunakan teknik random sampling. 
Kelas yang dijadikan sampel adalah kelas yang dianggap dapat memberikan informasi yang berhubungan dengan tujuan penelitian, yaitu kelas VII.6 sebagai kelas eksperimen dan kelas VII.2 sebagai kelas kontrol.

\section{Prosedur Penelitian}

Prosedur penelitian dibagi atas tiga tahap, yaitu tahap persiapan, tahap pelaksanaan dan tahap akhir. Pada tahap persiapan, mempersiapkan semua yang diperlukan dalam penelitian seperti menetapkan jadwal penelitian, menentukan kelas sampel, dan mempersiapkan instrumen penelitian.

Pada tahap pelaksanaan, pengumpulan data atau informasi sedang dilakukan pada kelas sampel. Pada tahap penyelesaian ini menganalisis tes akhir kemampuan komunikasi matematis peserta didik. Kemudian menganalisis kemampuan komunikasi matematis peserta didik dengan menggunakan uji-t.

\section{Data, Instrumen, dan Teknik Pengumpulan Data}

Sumber data yang digunakan dalam penelitian ini adalah data primer dan data sekunder. Data primer adalah data yang langsung diambil dari sampel yang diteliti. Data primer dalam penelitian ini adalah kemampuan komunikasi matematis peserta didik kelas eksperimen dan kelas kontrol. Data sekunder adalah data yang diperoleh dari orang lain. Data sekunder dari penelitian ini adalah jumlah peserta didik yang menjadi populasi dan sampel dalam penelitian ini, serta data nilai ujian tengah sesmester 1 peserta didik kelas VII MTsN Bungus Teluk Kabung Padang tahun pelajaran 2017/2018.

Instrumen yang digunakan dalam penelitian ini adalah tes akhir. Tes akhir mengandung indikator kemampuan komunikasi matematis peserta didik yaitu 1) Menyajikan pernyataan matematika secara lisan, tertulis, gambar dan diagram, 2) Mengajukan dugaan, 3) Melakukan manipulasi matematika, dan 4) Menarik kesimpulan.

Instrumen diuji cobakan terlebih dahulu di kelas VII.5 MTsN Bungus Teluk Kabung Padang pada tanggal 20 Oktober 2017. Dari soal uji coba tes akhir kemampuan komunikasi matematis terdapat 5 item soal diperoleh tingkat kesukaran sebanyak 2 butir soal berkriteria mudah dan 3 butir soal berkriteria sedang. Daya pembeda yang diperoleh untuk semua soal signifikan dan klasifikasi soal diterima/baik dengan reliabilitas 0,62. Menurut kriteria dalam Arikunto (2006:196) instrumen tersebut reliabel. Untuk mengukur kemampuan komunikasi matematis peserta didik digunakan rubrik analitik. Menurut Iryanti (2004: 13) “Rubrik analitik adalah pedoman untuk menilai berdasarkan beberapa kriteria yang ditentukan”. Dengan menggunakan rubrik ini dapat dianalisa kelemahan dan kelebihan seorang peserta didik terletak pada kriteria yang mana 


\section{Teknik Analisis Data}

Analisis data penelitian dilakukan untuk menguji hipotesis yang diajukan dalam penelitian ini. Data yang didapat dari hasil tes akhir akan dianalisis dengan tujuan, untuk mengetahui apakah terdapat perbedaan kemampuan komunikasi matematis peserta didik yang menggunakan Metode ProbingPrompting Learning dengan kemampuan komunikasi matematis yang tidak menggunakan Metode Probing-Prompting Learning

Teknik yang digunakan untuk menganalisis data kemampuan komunikasi matematis peserta didik yaitu dengan statistik deskriptif yaitu persentase dan rata-rata. Adapun interpretasi kemampuan komunikasi matematis menurut Djamarah \& Zain, (2013: 210) disajikan pada tabel di bawah ini:

Tabel 2. Interpretasi kemampuan komunikasi matematis

\begin{tabular}{lc}
\hline Nilai Persentase & Kategori \\
\hline $99 \%-100 \%$ & Istimewa \\
$76 \%-99 \%$ & Baik Sekali \\
$60 \%-75 \%$ & Baik \\
$0-60 \%$ & Kurang \\
\hline
\end{tabular}

Sumber: Djamarah \& Zain, (2013: 210)

Analisis data tes akhir bertujuan untuk menguji apakah hipotesis penelitian diterima atau ditolak. Dari data tes akhir dilakukan uji normalitas dan homogenitas diperoleh hasil analisis, jika hasil tes akhir adalah normal dan homogen, maka rumus untuk uji hipotesis yang digunakan adalah uji-t seperti yang dikemukakan oleh Sudjana (2005:243) sebagai berikut:

$$
\mathrm{t}=\frac{\overline{x_{1}}-\overline{x_{2}}}{s \sqrt{\frac{1}{n_{1}}+\frac{1}{n_{2}}}}
$$

dengan,

$$
S^{2}=\frac{\left(n_{1}-1\right) s_{1}{ }^{2}+\left(n_{2}-1\right) s_{2}{ }^{2}}{n_{1}+n_{2}-2}
$$

Kriteria pengujian: Kriteria Hipotesis $H_{0}$ diterima jika $t_{\text {hitung }}<t_{\text {tabel }}$ dilihat pada daftar distribusi-t dengan derajat kebebasan $\mathrm{df}=\mathrm{n}_{1}+\mathrm{n}_{2}-2$ dengan peluang $(1-\alpha) \cdot \mathrm{H}_{\mathrm{o}}$ ditolak jika $t_{\text {hitung }} \geq t_{\text {tabel }}$ dilihat pada daftar distribusi-t dengan derajat kebebasan $\mathrm{df}=\mathrm{n}_{1}+\mathrm{n}_{2}-2$ pada taraf signifikan 0,05.

\section{HASIL PENELITIAN DAN PEMBAHASAN}

Pada bagian ini dijelaskan hasil penelitian yang telah diperoleh dari pelaksanaan pembelajaran dengan menerapkan Metode Probing-Prompting Learning, kemudian hasilnya dibandingkan dengan hasil yang diperoleh dari pelaksanaan pembelajaran dengan menerapkan pembelajaran pendekatan saintifik.

Data kemampuan komunikasi matematis peserta didik diperoleh setelah diberikan tes akhir kepada kedua kelas sampel, yaitu VII. (kelas kontrol) dan VIII.6 (kelas eksperimen). Pelaksanaan tes akhir diikuti oleh 36 orang peserta didik pada kelas eksperimen dan kelas. Tes akhir yang diberikan terdiri atas 5 butir soal esay dengan alokasi waktu 90 menit. Perhitungan yang dilakukan pada hasil tes 
kemampuan komunikasi matematis peserta didik dapat dilihat pada tabel 3 berikut:

Tabel 3. Perhitungan Hasil Tes Akhir Peserta Didik Kelas Sampel

\begin{tabular}{lcc}
\hline Deskripsi Data & \multicolumn{2}{c}{ Kelas Ekspe Kelas Kontrol } \\
\hline Jumlah PS & 36 & 36 \\
Rata-rata & 80,00 & 73,42 \\
Nilai tertinggi & 100 & 97 \\
Nilai terendah & 47 & 44 \\
Simpangan baku & 13,91 & 16,20 \\
Variances $\left(S^{2}\right)$ & 193,49 & 262,36 \\
Jumlah ketuntasan & 26 & 20 \\
Persent ketuntasan & $72 \%$ & $56 \%$ \\
\hline
\end{tabular}

Berdasarkan hasil perhitungan yang terdapat pada tabel 3 dapat dilihat bahwa ratarata kemampuan komunikasi matematis peserta didik kelas eksperimen lebih tinggi daripada rata-rata kemampuan komunikasi matematis peserta didik pada kelas kontrol. Nilai tertinggi yang diperoleh pesertad didik kelas eksperimen lebih tinggi daripada nilai tertinggi kelas kontrol. Simpangan baku kelas eksperimen juga lebih tinggi dari pada simpangan baku kelas kontrol.

Perhitungan pada Tabel 3 merupakan gambaran umum bahwa kemampuan komunikasi matematis peserta didik pada kelas eksperimen lebih tinggi dari pada kemampuan komunikasi matematis peserta didik pada kelas kontrol. Berikut ini disajikan data yang lebih rinci mengenai rata-rata hasil tes akhir peserta didik pada kelas sampel untuk masing-masing indikator kemampuan komunikasi matematis.
Tabel 4. Data Tes Kemampuan Komunikasi Matematis Setiap Butir Soal Di Kelas Sampel

No. Indikator Kemampuan So Sk Eksp Kont

\begin{tabular}{lcrcc} 
Komunikasi Matematis & al & or & $\bar{x}$ & $\bar{x}$ \\
\hline 1. Menyajikan pernyataan & 1 & 8 & 6,50 & 7,00 \\
1 matematika secara & 3 & & 7,34 & 6,72 \\
lisan, tertulis, gambar, & 4 & & 6,64 & 6,42 \\
atau diagram. & 5 & & 7,34 & 6,34
\end{tabular}

2. Mengajukan dugaan (conjectures).

3. Melakukan manipulasi matematika.

$4,87 \quad 4,09$

$4,71 \quad 4,25$

$4,40 \quad 3,92$

$6,336,30$

$\begin{array}{lllll} & 2 & 8 & 7,10 & 6,49 \\ & 3 & & 6,72 & 6,10 \\ & 4 & & 7,57 & 6,26 \\ & 5 & & 3,55 & 3,17 \\ & & & & \\ & 3 & 6 & 3,48 & 3,40 \\ \text { Jumlah }(x) & 4 & & 3,50 & 3.05 \\ & 5 & & & \\ & & 80,00 & & 73,42\end{array}$

Dilihat dari tabel di atas, terdapat pula interpretasi presentase kemampuan komunikasi matematis peserta didik yang dikemukakan oleh Djamarah dan Zain (2013: 210) yaitu sebagai berikut:

Tabel 5. Interpretasi Persentase Kemampuan Komunikasi Matematis

\begin{tabular}{|c|c|c|c|c|}
\hline $\begin{array}{c}\text { Indikat } \\
\text { or }\end{array}$ & $\begin{array}{l}\text { Eks } \\
\%\end{array}$ & $\begin{array}{l}\text { Interpret } \\
\text { asi Eksp }\end{array}$ & $\begin{array}{c}\text { Kontr } \\
\text { ol } \\
\% \\
\end{array}$ & $\begin{array}{c}\text { Interpre } \\
\text { tasi } \\
\text { Kontrol }\end{array}$ \\
\hline 1 & $85,65 \%$ & $\begin{array}{c}\text { Baik } \\
\text { Sekali }\end{array}$ & $83,74 \%$ & $\begin{array}{l}\text { Baik } \\
\text { Sekali }\end{array}$ \\
\hline 2 & $85,28 \%$ & $\begin{array}{c}\text { Baik } \\
\text { Sekali }\end{array}$ & $75,46 \%$ & Baik \\
\hline 3 & $63,89 \%$ & $\begin{array}{c}\text { Baik } \\
\text { Sekali }\end{array}$ & $75,23 \%$ & Baik \\
\hline 4 & $85,65 \%$ & Baik & $59,26 \%$ & $\begin{array}{c}\text { Kurang } \\
\text { Baik }\end{array}$ \\
\hline
\end{tabular}


Keterangan:

1. Menyajikan pernyataan matematika secara lisan, tertulis, gambar, dan diagram.

2. Mengajukan dugaan (conjectures).

3. Melakukan manipulasi matematika.

4. Menarik kesimpulan.

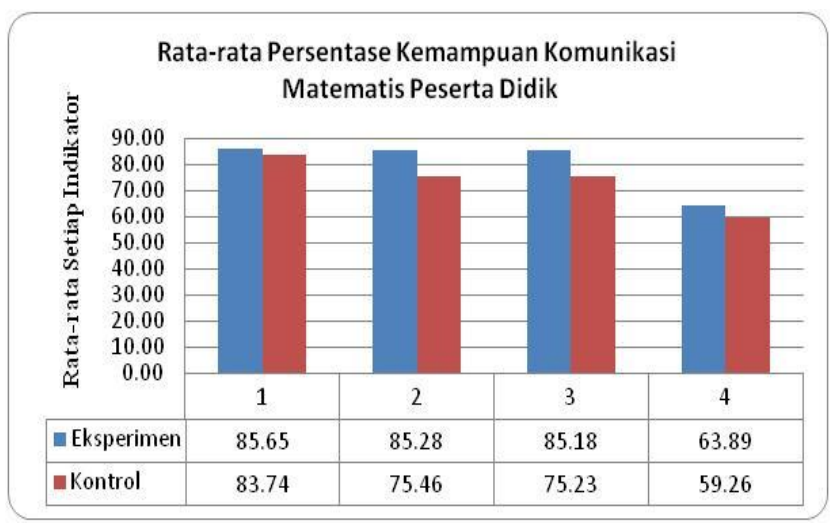

Gambar 2. Histogram Persentase Rata-Rata Kemampuan Komunikasi Matematis Peserta Didik Kelas Sampel Untuk Setiap Indikator

Berdasarkan data pada tabel 3 dan Gambar 2, secara umum tampak bahwa rata-rata untuk setiap indikator kemampuan komunikasi matematis peserta didik pada kelas eksperimen lebih tinggi dibandingkan rata-rata kemampuan komunikasi matematis pada kelas kontrol. Dari data pada tabel 3 dan tabel 4 dapat disimpulkan bahwa kemampuan komunikasi matematis peserta didik pada kelas eksperimen lebih tinggi dari pada kelas kontrol.

Untuk menarik kesimpulan tentang data tes akhir komunikasi matematis peserta didik dilakukan analisis secara statistik. Sebelum uji statistik untuk hipotesis, terlebih dahulu dilakukan uji normalitas dan uji homogenitas. Berdasarkan perhitungan uji normalitas menggunakan uji Lilliefors diperoleh perbandingan $L_{\text {tabel }}$ dengan $L_{0}$ dimana didapatkan semua data berdistribusi normal pada taraf kepercayaan 95\%. Untuk lebih jelasnya dapat diihat pada tabel dibawah ini:

Tabel 5. Tabel perbandingan $\mathrm{L}_{0}$ dan $\mathrm{L}_{\text {tabel }}$

\begin{tabular}{|c|c|c|c|c|c|}
\hline No & $\begin{array}{l}\text { Kela } \\
\text { s }\end{array}$ & $\mathrm{L}_{0}$ & $\mathrm{~L}_{\text {tabel }}$ & $\begin{array}{l}\text { Kesimpul } \\
\text { an }\end{array}$ & Ket \\
\hline \multirow[t]{2}{*}{1} & Eks & 0,07 & 0,147 & $\mathrm{~L}_{0}<\mathrm{L}_{\text {tabel }}$ & Data Normal \\
\hline & p & 5 & 7 & & \\
\hline \multirow[t]{2}{*}{2} & Kon & 0,08 & 0,147 & $\mathrm{~L}_{0}<\mathrm{L}_{\text {tabel }}$ & Data Normal \\
\hline & $t$ & 4 & 7 & & \\
\hline
\end{tabular}

untuk melihat apakah kedua kelompok data mempunyai variansi yang homogen atau tidak. Pengujian ini dilakukan dengan menggunakan uji F.

Nilai $F_{\text {tabel }}$ pada taraf $\alpha=0,05$ dengan derajat kebebasan $(\mathrm{df})=(35,35)$ adalah 1,69, maka $F_{\text {hitung }}(0,74)<F_{\text {tabel }}(1,69)$. Dengan demikian kedua kelas sampel memiliki variansi yang homogen.

Berdasarkan uji normalitas dan homogenitas variansi yang telah dilakukan, ternyata kedua kelas sampel berdistribusi normal dan mempunyai varians yang homogen. Dengan demikian, untuk mengetahui apakah hipotesis diterima atau tolak digunakan uji T.

Kriteria pengujian pada uji hipotesis ini, jika $t_{\text {hitung }}>t_{\text {tabel }}$ maka $H_{0}$ ditolak dan $H_{1}$ di terima.Dengan $\alpha=0,05$ dan $d k=70$ maka diperoleh $t_{\text {tabel }}=1,66$. Dengan demikian terlihat bahwa $t_{\text {hitung }}(1,82)>t_{\text {tabel }}(1,66)$.

Berdasarkan deskripsi dan analisis data didapat bahwa kelas eksperimen dan kelas kontrol terdapat perbedaan yang signifikan artinya hasil tes akhir kemampuan komunikasi matematis peserta didik yang diajar dengan Metode Probing-Prompting Learning lebih tinggi 
daripada yang tidak diajar dengan Metode Probing-Prompting Learning. Hal ini disebabkan karena perlakuan yang diberikan berbeda pada kelas eksperimen $\left(\mathrm{VII}_{6}\right)$ yang diajarkan dengan Metode Probing-Prompting Learning, sedangkan dikelas kontrol $\left(\mathrm{VII}_{2}\right)$ tidak diajar dengan Metode Probing-Prompting Learning.

Penelitian ini akan mengemukakan pembahasan berkaitan dengan permasalahan penelitian dengan mengacu pada kemampuan komunikasi matematis peserta didik. Berdasarkan penelitian yang telah dilakukan kelas eksperimen dari pertemuan pertama hingga pertemuan terakhir mengalami peningkatan.

Dalam setiap pertemuan terlihat peningkatan belajar matematika peserta didik, dan dari beberapa peserta didik telah memperlihatkan hasil yang optimal. Hal tersebut terlihat dari keaktifan dan kemauan peserta didik untuk belajar matematika. Kemampuan komunikasi matematis peserta didik dengan menggunakan Metode ProbingPrompting Learning ini menunjukkan hasil yang baik. Hal ini dapat dilihat dari kemampuan peserta didik dalam presentasi, bertanya dan menanggapi pertanyaan dengan baik pada saat diskusi, serta nilai latihan soal kemampuan komunikasi matematis peserta didik pada lembar kerja peserta didik (LKPD) yang selalu mengalami peningkatan setiap pertemuan dan juga hasil tes akhir peserta didik yang cukup memuaskan dari sebelumnya.
Ditinjau dari tes akhir, diperoleh bahwa kemampuan komunikasi matematis peserta didik kelas eksperimen yang diajar dengan Metode Probing-Prompting Learning lebih tinggi dari pada kemampuan komunikasi matematis peserta didik yang tidak diajar dengan Metode Probing-Prompting Learning. Hal ini terlihat dari nilai rata-rata kelas eksperimen lebih tinggi dari pada kelas kontrol. Berdasarkan uraian tersebut, jelas terlihat bahwa kemampuan komunikasi matematis yang diajar dengan Metode Probing-Prompting Learning dalam pembelajaran matematika memberikan dampak yang positif bagi peserta didik

\section{SIMPULAN DAN SARAN}

\section{Simpulan}

Berdasarkan hasil analisis data dan pembahasan BAB IV, maka dapat disimpulkan bahwa kemampuan komunikasi matematis peserta didik kelas VII MTsN Bungus Teluk Kabung Padang yang diajar dengan menggunakan Metode Probing-Prompting Learning lebih tinggi dari pada kemampuan komunikasi matematis peserta didik yang tidak diajar dengan Metode Probing-Prompting Learning tahun Ajaran 2017/2018.

Hasil penelitian menunjukan bahwa ratarata tes akhir peserta didik pada kelas eksperimen adalah 80,00 dan kelas kontrol adalah 73,42. Jika dilihat dari ketuntasan hasil tes akhir peserta didik pada kelas eksperimen terdapat 26 orang peserta didik yang mencapai KKM dari 36 orang peserta didik, dengan persentase ketuntasan $72 \%$. Sedangkan pada 
kelas kontrol terdapat 20 peserta didik yang mencapai KKM dari 36 orang peserta didik dengan persentase ketuntasan $56 \%$.

Pengolahan data hasil tes akhir dilakukan melalui uji hipotesis yang menggunakan uji-t. Setelah dilakukan perhitungan sehingga diperoleh $t_{\text {hitung }}(1,82)>t_{\text {tabel }}(1,66)$ dengan taraf kepercayaan 95\%. Ini berarti $t_{\text {hitung }}>t_{\text {tabel }}$ hal ini menunjukan bahwa hipotesis dalam penelitian ini diterima.

\section{Saran}

Berdasarkan kesimpulan yang diperoleh dari penelitian ini maka peneliti memberikan saran-saran kepada guru matematika MTs/SMP pada umumnya dan guru matematika MTsN Bungus teluk Kabung Padang pada khususnya menerapkan Metode Probing-Prompting Learning dengan mengunakan alokasi waktu yang lebih dengan pengaturan (manajemen waktu) yang baik sehingga dapat digunakan sebagai salah satu alternatif untuk meningkatkan kemampuan komunikasi matematis peserta didik, pendidik menerapkan Metode Probing-Prompting Learning pada materi yang memuat soal-soal penerapan dan berhubungan dengan kemampuan komunikasi matematis, kepada peneliti berikutnya, agar dapat menyempurnakan kekurangan dari penelitian ini untuk mendapatkan hasil yang lebih optimal. Seperti merancang skenario pembelajaran secara proporsional, sehingga keterbatasan penelitian dalam proses pembelajaran tidak ditemui lagi, dan kepada para pembaca diharapkan agar hasil penelitian ini dijadikan sebagai salah satu bahan untuk memperkaya wawasan yang telah dimiliki.

\section{REFERENSI}

Abdul, G. (2017). Metode Pembelajaran Probing Prompting Learning . Diakses tanggal 26 Januari 2017 dari http://abdulgopuroke.blogspot.co.id//2 017/01/metode-pembelajaran-probingprompting.html.

Arikunto, Suharsimi. (2006). Prosedur Penelitian, Jakarta: Rineka Cipta

Daryanto. (2014). Pendekatan Pembelajaran Saintifik. Yogyakarta: Gava Media.

Djamarah,S.B \& Zain, A. (2013). Strategi Belajar Mengajar. Rineka Cipta: Jakarta.

Hasbullah. (2006). Dasar-dasar Ilmu Pendidikan. Jakarta: PT Raja Grafindo Persada.

Huda, Miftahul. (2013). Model-Model Pengajaran dan Pembelajaran, Yogyakarta: Pustaka Pelajar.

Hamzah, Uno. (2011). Model Pembelajaran Menciptakan Proses Belajar Mengajar yang Kreatif dan Efektif, Jakarta: Bumi Aksara

Iryanti, Puji. (2004). Penilaian Unjuk Kerja, Yogyakarta: Depdiknas.

Istarani, M. Ridwan. (2014). 50 Tipe Pembelajaran Kooperatif, Medan: CV Media Persada.

Kemendikbud. (2014). Materi Pelatihan Implementasi Kurikulum 2013. Jakarta: Kementrian Pendidikan dan Kebudayaan.

Lie, Anita. (2002). Cooperative Learning. Jakarta : Grasindo

Mulyasa. (2011). Menjadi Guru Profesional, Bandung : Remaja Rosdakarya. 
Prawironegoro, Pratiknyo (1985). Evaluasi Belajar Khusus Analisis Soal untuk Bidang Studi Matematika. Jakarta: P2LPTK

Shadiq, Fadjar. (2009). Kemahiran Matematika,Yogyakarta: Departemen Pendidikan Nasional.

Sanjaya, Wina. (2012). Media Komunikasi Pembelajaran. Jakarta: Kencana Prenada Media Group.

Slameto. (2003). Belajar dan Faktor-faktor yang Mempengaruhinya. Jakarta: Rineka Cipta

Suherman, Erman. (2003). Strategi Pembelajaran Matematika Kontemporer, Bandung: JICAUniversitas Pendidikan Indonesia.
Suryabrata, Sumandi. (2008). Metode Penelitian. Yogyakarta: UGM PT. Raja Gravindo Persada.

Susanto, Ahmad. (2013). Teori Belajar dan Pembelajaran di Sekolah Dasar. Jakarta: Karisma Putra Utama.

Suyitno, Amin. (2004). Dasar-Dasar Dan Proses Pembelajaran Matematika I. Semarang: Jurusan Matematika UNNES.

Sudjana, Nana. (2005). Dasar-dasar Proses Belajar Mengajar. Bandung: Sinar Baru.

Tim Penyusun. (2007). Pedoman Penulisan Skripsi IAIN Imam Bonjol Padang, Padang: IAIN Imam Bonjol Padang.

Widya, Ananda. (2010). Pengaruh Penerepan Teknik Probing-Promting Terhadap Kemampuan Penalaran Matematis Siswa Kelas VIII SMP Negeri 13 Padang. IAIN IB Padang (skripsi tidak diterbitkan). 